\title{
Human Resources Management Activities Adopted in the Value Chain Model and their Impact on the Organizational Sustainability-An Empirical Study in the Jordanian Pharmaceutical Companies
}

\author{
Abdul Azeez Badir Alnidawi ${ }^{1}$, Fatimah Musa Omran ${ }^{2}$ \\ ${ }^{1}$ Business Administration Department, Al-Zaytoonah University, Amman, Jordan \\ ${ }^{2}$ Fatima_omran84@Yahoo.com \\ Correspondence: Abdul Azeez Badir Alnidawi, Business Administration Department, Al-Zaytoonah University, Queen \\ Alia Airport Street, P.O. BOX 130 Amman11733, Jordan. Tel: 00962-799987302. \\ E-mail:dr54azezalnidawy@yahoo.com
}

\author{
Received: May 4, 2016 \\ doi:10.5539/ibr.v9n8p106 \\ Accepted: May 12, 2016 \\ Online Published: July 25, 2016 \\ URL: http://dx.doi.org/10.5539/ibr.v9n8p106
}

\begin{abstract}
The current situation that business organizations now is featured by different changing and developing work environment with difficulty and risk in achievement of their sustainability, continuity and success in addition to the existence of a set of great and extended challenges and competition, therefore, the organizations seek to keep pace with development through creation of ability to better use their provided resources in order to achieve sustainability and create the competitive advantage that makes them superior to the competing organizations.

The occurrence of a set of phenomena in the knowledge economy had an obvious reflection on the business organizations that started to search new mechanisms for competition and ensure survival, continuity and create the added value through using the value chain model and focusing on the main and supportive activities in this model. The role of human resources management activities was appeared as supportive activities and an essential requirement to deal with these great challenges either they were local, regional or international where the human resources activities represent the main generator to produce new ideas, development of old ideas and the participation in supporting the main activities of the organizations, enabling them to expand its market share, maximize the organization value making it in a position through which it will be able to seize the opportunities, achieve the competitive advantage, survive, continue in the current market and think to find future markets to serve customers and realize their satisfaction.
\end{abstract}

This study comes with the purpose to demonstrate the impact of human resources management activities adopted in the value chain model on organizational sustainability with its different dimensions in the Jordanian environment.

Keywords: human resources management activities, value chain, organizational sustainability

\section{Introduction}

Value chain is one of the modern concept in the administrative thought and its application rules have not been established enough in the business sector despite it was widely taken in the business administration literature and the value chain model is one of the used models in the organization as it represents the general framework of industry and other sectors (Al-Nsour, 2009). The organization work nature may be understood through the value chain model, its capabilities and uses for its different resources in its various operations that can determine through its vulnerabilities to be treated and support strong points that participate in addition of great value working on realization of the competitive advantage (Al-Sakarneh, 2005).

The value chain model is composed of a set of linked activities that each add a value to a previous activity, and these activities are divided into two major kinds (Main activities and Supportive activities). The human resources management activity is one of the supportive activities in the value chain model as it is linked to all other organization activities and also its participation in these activities efficiency and effectiveness improvement and is the basis on which business organizations depend to build competencies and qualifications that grant a competitive advantage to the organization making it superior to its rivals. On the other side, the organizational sustainability is a subject matter which gained wide attention either from researchers or business organization in different areas. Where the matter of organizational sustainability has become a part and one of the main priorities in the various strategies adopted by 
business organizations for its long-term effect and serious participation in the organization success and continuity in a contemporary environment with its features.

Pharmaceutical Industry Companies Sector in Jordan is a sector with great participation in the Jordanian Economy and despite that it faces high challenges on the local, regional and international level resulting from continuous progress in pharmaceutical industry area, therefore, these companies find itself in necessity of continuous development in order to keep up with intense competition in this sector.

From the foregoing, this study works on linking the variable of human resources management activities adopted in the value chain model to the variable of the organizational sustainability with its dimensions within the Pharmaceutical Industry Companies Sector through studying of human resources management activities adopted in the value chain model and their influence on the organizational sustainability, as an empirical study in the Pharmaceutical Industry Companies Sector.

\section{Methodology of Study}

\subsection{Problem of Study}

Business organizations have realized, that within the current competitive environment and within pressures and threats they face, that they are committed to adopt the concept of the organizational sustainability represented in (sustainability of customers' needs assessment, sustainability of knowledge of current and future markets, sustainability of organizational flexibility, sustainability of competitive ability) (Al-Bakri, 2013). Which has imposed to these organizations the necessity to seek for realization of organizational sustainability requirements and among these most important requirements related to human resources management that works on the staff development and supports other operations of the organization which participate in attraction of new clients in addition to preserve its current clients with their satisfaction, fidelity and support of the organization competitiveness (Al-Mashharawi, 2015). Through both researchers revision to these different activities that participate in the realization of this requirement, it was founded that human resources management activities adopted in the value chain model represent the substantial success of these companies that face many challenges affecting directly their sustainability and continuity. From here the study problem was axed embodied in that Jordanian Pharmaceutical Industry Companies require distinctive human resources management activities participating in the organizational sustainability realization, success and to achieve their goals with high efficiency and effectiveness also to face this problem methodically that has been formulated in a scientific and methodical manner through the following major question:

- Is there a statistically significant impact to the human resources management activities adopted in the value chain model on the realization of organizational sustainability (sustainability of customers' needs assessment, sustainability of knowledge of current and future markets, sustainability of organizational flexibility, sustainability of competitive ability) in the Jordanian Pharmaceutical Industry Companies Sector?.

\subsection{Objectives of Study}

The main objective of the study is represented by the determination of the impact of the human resources management activities adopted in the value chain model on the realization of organizational sustainability in the Jordanian Pharmaceutical Industry Companies Sector, and the following sub-objectives shall be ramified from this objective:

1. Definition of the organizational sustainability concepts and their requirements, value chain and its adopted activities in addition to the concept of the human resources management activities adopted in the value chain model.

2. Explanation of the participation of the human resources management activities adopted in the value chain model on the realization of organizational sustainability with its dimensions adopted in this study.

3. Constitution of practical framework including the statistical analysis results that support and enhance the theoretical framework in addition to the submission of conclusions and recommendations that serve decision-makers in this sector.

\subsection{Importance of Study}

The study gains its importance from the study sector importance, which is the Jordanian Pharmaceutical Industry Sector as it is directly linked to human life in addition to that it is a great sector in terms of workers and investment in Jordan, where this study helped in knowledge of challenges that hinder the development and progress of this sector, therefore, the study importance can be determined by the following:

\section{Scientific importance of the study}

This study is considered as a new reference to researchers and academics in Jordan and Arab World, where this study presented theoretical and practical framework about value chain model and its major and supportive activities, also about organizational sustainability with its dimensions and environmental challenges in which these companies work. 
This study constitutes a launching basis for researchers toward wider areas in search and investigation on the scientific variables set used in this study and related challenges and its impact in this sector also other sectors.

\section{Practical importance of Study}

This study provides a modern and contemporary reference to administrative leaders and decision-makers in the studied organizations, where it explains the impact of the human resources management activities adopted in the value chain model on the creation of organizational sustainability with its dimensions, facing challenges and benefit from this study to generate new ideas and solutions to treat the problems that they face which reflects positively on the organizations continuity and success.

\section{Economic importance of Study}

The economic importance of the study is materialized through highlighting the most important factor that contribute to the achievement of organizational sustainability, which is the human resources management activities adopted in the value chain model characterized by a great importance in terms of economic situation support to the organization as attracting new customers, keeping the current customers as well as supporting competitiveness for the organizations and helping them to exploit available chances and avoid threats that reflect positively on the market share of the studied organizations and on the growth, continuity and success.

\subsection{Model of Study}

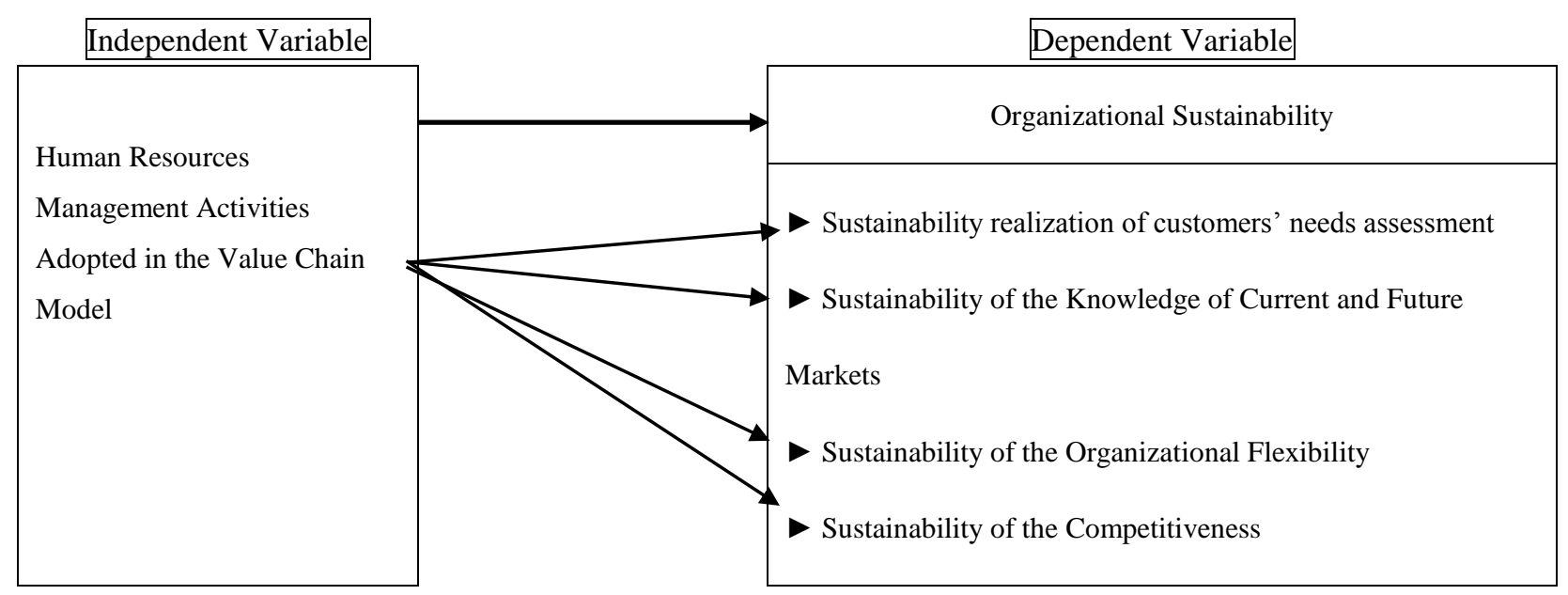

Figure 1. Model of Study

Reference: - prepared by researchers

\subsection{Hypotheses of the Study}

Hypotheses of this study have been formulated according to the question of the study, its objectives and its model and the hypotheses of the study are represented in the following hypotheses:

The first main hypothesis

Ha1: There is a statistically significant impact for the human resources management activities adopted in the value chain model on the realization of organizational sustainability in the Jordanian Pharmaceutical Industry Companies Sector . The ramifications of this hypothesis are the following sub-hypotheses:

The first sub- hypothesis

Ha1.1: There is a statistically significant impact for the human resources management activities adopted in the value chain model on the sustainability realization of customers' needs assessment in the Jordanian Pharmaceutical Industry Companies Sector.

Ha1.2: There is a statistically significant impact for the human resources management activities adopted in the value chain model on the sustainability realization of the knowledge of current and future markets in the Jordanian Pharmaceutical Industry Companies Sector.

Ha1.3: There is a statistically significant impact for the human resources management activities adopted in the value chain model on the sustainability of organizational flexibility in the Jordanian Pharmaceutical Industry Companies Sector. 
Ha1.4: There is a statistically significant impact for the human resources management activities adopted in the value chain model on the sustainability of competitiveness in the Jordanian Pharmaceutical Industry Companies Sector.

\subsection{Population and Sample of the Study}

The population of the study consists of workers in the Jordanian Pharmaceutical Companies Sector amounted to (21) companies and (4) companies have been selected, they are:

1. Al-Hickam Pharmaceuticals Company.

2. Arab Pharmaceutical Manufacturing Company.

3. Jordanian Dar Al-Dawa Company.

4. Arab Center for Pharmaceutical and Chemical Industries Company.

Where the number of the Administrative Staff in these companies is amounted to (1600) persons representing the population of the study. Based on statistical equations used to determine the size of the sample (140) persons have been identified and distributed as follows:

Table 1. Names of the Companies Representing the Sample of the Study and Staff Number

\begin{tabular}{cc} 
Name of the Company & $\begin{array}{c}\text { Number of Distributed } \\
\text { Questionnaires }\end{array}$ \\
\hline Al-Hickam Pharmaceuticals Company & 40 \\
Arab Pharmaceutical Manufacturing Company & 40 \\
Jordanian Dar Al-Dawa Company & 30 \\
Arab Center for Pharmaceutical and Chemical Industries Company & 30 \\
Total & 140 \\
\hline
\end{tabular}

\subsection{Means of Collecting Information}

The means of collecting information are divided into two main parts:

First Part: An audit and survey were conducted to the various theoretical and field studies where precise scientific books and journals, master and doctoral theses in addition to the reliable information on Internet were reviewed. But the practical information that serve study are collected by both researchers through fields visits to the pharmaceutical industry companies and performing a set of interviews with many administrators in these organizations and human resources management.

Second Part: A questionnaire was developed to reflect the impact of the human resources management activities adopted in the value chain model on the creation of organizational sustainability of companies where advantage was taken of the questionnaires and previous studies on this question and have been presented to a number of arbitrators to ascertain the authenticity of content also the necessary amendments were made to the paragraphs of the questionnaire and then were distributed to the study sample. The likert quintuple scale was used to measure the content of the questionnaire as follows: (5degree to the Strongly Agree, 4degree to the Agree, 3degree to the Neutral, 2degreeto the Disagree, 1degreeto the Strongly Disagree). As for the used statistical methods, the Statistical Package for Social Sciences (SPSS) has been used as it serves the study objectives.

\subsection{Terms Definitions of the Study}

The study has included a number of variables, as explained by the study model and we find necessary to explain these variables for achieving the desired objective as the following:

\section{Value Chain Model}

It is a design including a number of main activities and supportive activities performed by the organization to achieve its objectives and competition where organization analysis and installation are performed through this model and to identify its current and future resources contributing to the achievement of an added value to the organization and its clients better than the rival organizations (Stevenson, 2007).

\section{Human Resources Management Activities}

It is a set of activities within the value chain model that are classified among the supportive activities and contributing to Staff development, which lead to the achievement of competition and new value of the organization (Alnidawi, 2009).

\section{Organizational Sustainability:}

It is the process of successful sustainability and continuity creation of the organization in various fields in the light of unstable business environment and contribute to the achievement of the organization objectives with high efficiency and effectiveness in a continuous manner (Alnidawi, 2015). 


\section{Theoretical Aspect of the Study}

\subsection{Value Chain Model}

The vision to the organizations in the twenty-first century has changed than in the past, where it is regarded as a set of systems, of which the most important one is the General System of Performance that is called Value Chain Model working on the search of competitive advantage sources and its principles on the level of different activities of the organization (Evan, et al, 2007). Despite that the Value Chain Model was widely dealt by the various management literatures, but its bases did not enough established yet in the business organizations sector (Stevenson, 2007). A group of researchers has dealt with the notion of the value chain from different angles and the following is a presentation of some concepts that explain the value chain notion as the following:

Table 2. Value Chain Model Concept

\begin{tabular}{|c|c|c|}
\hline Term & Notion & Source \\
\hline $\begin{array}{l}\text { Value Chain } \\
\text { Model }\end{array}$ & $\begin{array}{l}\text { It is a term used in the business administration area, } \\
\text { which means all activities contributing to create a } \\
\text { value for the product starting by search, development, } \\
\text { engineering and manufacturing then to the customer. }\end{array}$ & (Castro et al, 2006) \\
\hline $\begin{array}{l}\text { Value Chain } \\
\text { Model }\end{array}$ & $\begin{array}{l}\text { It is an analytical tool that gives a precise vision to } \\
\text { the total organization performance and helps in the } \\
\text { determination of the factors, which affect in the } \\
\text { organization competitiveness. }\end{array}$ & (Evan, et al, 2007) \\
\hline $\begin{array}{l}\text { Value Chain } \\
\text { Model }\end{array}$ & $\begin{array}{l}\text { It is a group of activities through which a commodity } \\
\text { or service is formed and delivered to the clients, also } \\
\text { achieve their satisfaction. }\end{array}$ & (Flatt \& Stenley, 2008) \\
\hline $\begin{array}{l}\text { Value Chain } \\
\text { Model }\end{array}$ & $\begin{array}{l}\text { It is an analytical tool that works on partition and } \\
\text { analysis of main and supportive activities connected } \\
\text { in the organization that aim to realize the value in the } \\
\text { product, incomes, profits and share value. }\end{array}$ & (Koch, 2008) \\
\hline $\begin{array}{l}\text { Value Chain } \\
\text { Model }\end{array}$ & $\begin{array}{l}\text { It is an integrated model for the activities that achieve } \\
\text { a competitive advantage to the organization. }\end{array}$ & (Salmon, 2008) \\
\hline $\begin{array}{l}\text { Value Chain } \\
\text { Model }\end{array}$ & $\begin{array}{l}\text { It is a group of activities connected in the } \\
\text { organization that achieves the value starting from the } \\
\text { main inputs obtaining sources and until the product } \\
\text { final delivery to the clients. }\end{array}$ & (Dobni, 2010) \\
\hline $\begin{array}{l}\text { Value Chain } \\
\text { Model }\end{array}$ & $\begin{array}{l}\text { It is a group of analytical methods used by the } \\
\text { organization to compare its performance with its } \\
\text { competitive position in the environment it works. }\end{array}$ & $\begin{array}{l}\text { (Human \& Naude, } \\
\text { 2010) }\end{array}$ \\
\hline
\end{tabular}

The activities of the value chain model are combined with two types of activities, and as the following:

1. Main Activities: The activities contributing directly in the operation of commodity or service production and are represented in the following operations: (Inbound Logistics, Operations, Outbound Logistics, Marketing and Sales and Customers Services).

2. Supportive Activities: The activities that help and provide support for the main activities allowing them to perform their roles, achieve the organization main objective and conclude the following:
A. Firm infrastructure.
B. Human Resources Management Activities.
C. Development and Technology.
D. Materials Procurement.

The Figure 2 Explains the Value Chain

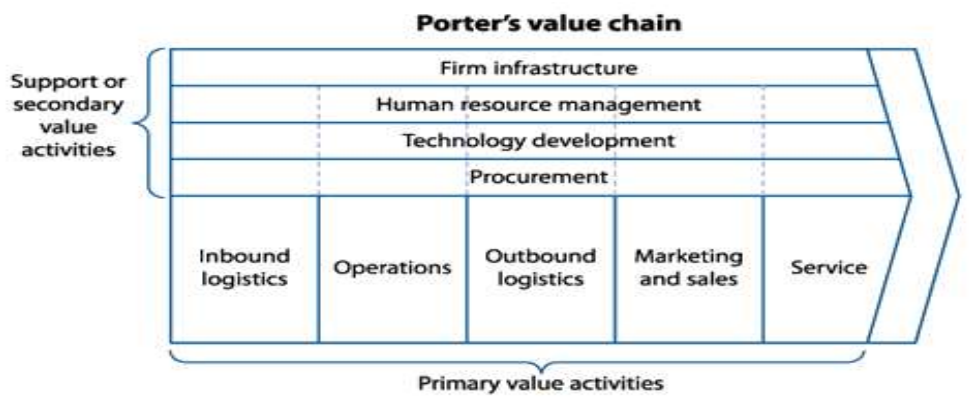

Figure 2. Value Chain Model 


\subsection{Human Resources Management Activities Adopted in the Value Chain Model}

We have explained that the value chain model include a number of activities, and among the prominent supportive activities in the model are the Human Resources Management Activities as they have a major and strategic role, where all other main and supportive activities depend on the human resources as they are the essential element in building competencies and capabilities that supplement the new added value to the organization through which the firm can create competitiveness and be superior to the rivals. It is meant by Human Resource Management Activities that they are (a group of different, continuous and organized activities linked to the human resource and classified within the supportive activities to other operations in the Value Chain Model that contribute to create the new added value. These activities include all functions, strategies, policies and programs related to the human element in the organization. Table 3 explains the prominent activities related to human resources as the following:

Table 3. Human Resource Management Activities

\begin{tabular}{ll}
\hline No. & Human Resources Management Activities Adopted in the Value Chain Model \\
\hline 1 & Continuous and specialized education for the staff \\
2 & Continuous development of staff communication abilities in the firm \\
4 & Development of teamwork methods for the staff \\
5 & Development of knowledge balance for the staff \\
6 & Enabling the staff in the firm \\
7 & Development of communications between the employees \\
8 & Development of the employees analytical and research skills \\
9 & Improvement of staff orientation toward the excellence strategy \\
10 & Staff psychological constitution and development of their creativity \\
11 & Development of the employees creative abilities \\
\hline
\end{tabular}

Source: (Bounchken \& Koch, 2007), (Cheraghi, et al, 2012)

These activities constitute a great importance for the firm and the figure no. (3) explains the importance of the human resources management activities adopted in the value chain model as the following:

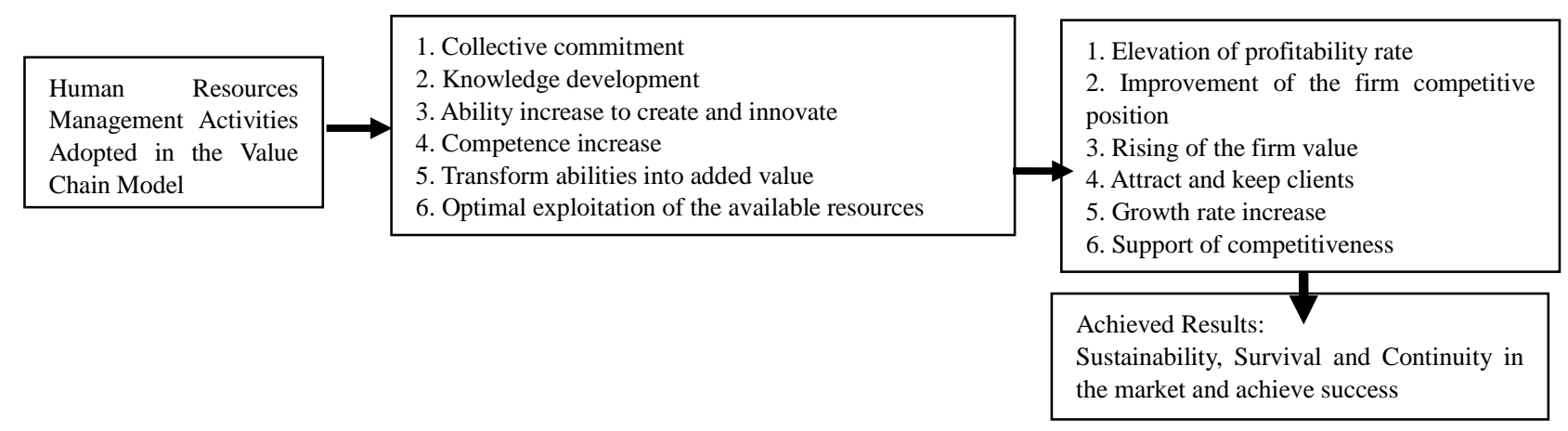

Figure 3. Human Resources Management Activities Adopted in the Value Chain Model

Reference: prepared by the researcher based on (Bounchken \& Koch, 2007), (Cheraghi, et al, 2012)

\subsection{Organizational Sustainability}

\subsubsection{Notion of Organizational Sustainability}

The business organizations have realized that in an environment of competition, pressures and threats that they face, they are committed to pursue the new organizational orientation represented in the adoption of the organizational sustainability concept since this notion has become a contemporary strategic orientation for business organizations in its interaction with the vocabulary of the changing business environment, and the table no. (4) explains the organizational sustainability concept as the following: 
Table 4. Organizational Sustainability Concept

\begin{tabular}{|c|c|c|}
\hline Variable & Concept & Reference \\
\hline $\begin{array}{l}\text { Organizational } \\
\text { Sustainability }\end{array}$ & $\begin{array}{l}\text { It is the operation of continuity and survival in the long-term business } \\
\text { environment with achievement of high performance indications that } \\
\text { confirm and support continuity and survival }\end{array}$ & (Baum, 2006) \\
\hline $\begin{array}{l}\text { Organizational } \\
\text { Sustainability }\end{array}$ & $\begin{array}{c}\text { It is an operation of sustainable value creation for current and future } \\
\text { generation }\end{array}$ & (David, 2007) \\
\hline $\begin{array}{l}\text { Organizational } \\
\text { Sustainability }\end{array}$ & $\begin{array}{l}\text { It is the operation to preserve the firm supplies, assets and its funds in } \\
\text { the long-term }\end{array}$ & $\begin{array}{l}\text { (Kotler and } \\
\text { Armstrong, 2007) }\end{array}$ \\
\hline $\begin{array}{l}\text { Organizational } \\
\text { Sustainability }\end{array}$ & $\begin{array}{l}\text { It is the operation of the firm continuity and stay strong in the } \\
\text { environment where it works for a long-term with the existence of } \\
\text { indications enhancing this continuity and confirm the increase of firm } \\
\text { power }\end{array}$ & $\begin{array}{l}\text { (Landrum \& } \\
\text { Edwards, 2009) }\end{array}$ \\
\hline $\begin{array}{l}\text { Organizational } \\
\text { Sustainability }\end{array}$ & $\begin{array}{l}\text { It is the operation of ideas generation correctly and methodically to } \\
\text { achieve continuous competence and effectiveness for the firm }\end{array}$ & $\begin{array}{c}\text { (Ebner \& } \\
\text { Baumgartner, 2010) }\end{array}$ \\
\hline $\begin{array}{l}\text { Organizational } \\
\text { Sustainability }\end{array}$ & $\begin{array}{c}\text { It is an operation of the firm activity realization through the optimal } \\
\text { usage of the firm supplies to transform continuously inputs to } \\
\text { valuable outputs for the client }\end{array}$ & (Elliot, 2011) \\
\hline $\begin{array}{l}\text { Organizational } \\
\text { Sustainability }\end{array}$ & $\begin{array}{l}\text { It is a set of administrative operations conducted by business } \\
\text { organizations to achieve economic and social competition } \\
\text { continuously }\end{array}$ & (AZua, 2012) \\
\hline
\end{tabular}

\subsubsection{Organizational Sustainability Requirements}

Organizational sustainability requirements may be seen according to the firm internal and external environment levels as the following:

\begin{tabular}{|c|c|}
\hline $\begin{array}{l}\text { Organizational sustainability requirements in the internal } \\
\text { environment }\end{array}$ & $\begin{array}{l}\text { Organizational sustainability requirements in the external } \\
\text { environment }\end{array}$ \\
\hline $\begin{array}{l}\text { 1-The organization commitment to a clear vision and } \\
\text { mission }\end{array}$ & $\begin{array}{l}\text { 1. Responding to the growth operations in the business } \\
\text { environment }\end{array}$ \\
\hline 2. Continuous commitment to operations of innovation & 2. Responding to the globalization requirements \\
\hline 3. Commitment to the development of knowledge & $\begin{array}{l}\text { 3. Exploring new markets and readiness to enter these } \\
\text { markets. }\end{array}$ \\
\hline 4. Human resource sustainable development & $\begin{array}{l}\text { 4. Enhance the cooperative relations networks between the } \\
\text { organization and various other parties }\end{array}$ \\
\hline 5. Achieve the staff functional satisfaction & 5. Achievement of elevated growth operations \\
\hline stainability requirements & 6. Supporting the firm competitiveness \\
\hline 7. Set-up a plan to achieve organizational sustainability & $\begin{array}{l}\text { 7. Attracting clients and working on their satisfaction } \\
\text { achievement }\end{array}$ \\
\hline 8. Positive change & 8. Increasing the firm market share \\
\hline 9. Optimal exploitation of the firm available resources & 9. Exact assessment of clients' needs \\
\hline 10. Achievement of high quality outputs & 10. Commitment to ethical standards \\
\hline
\end{tabular}

Reference: prepared by both researchers based on (Mowforth \& Munt, 2009)

\subsubsection{Organizational Sustainability Elements and Dimensions}

The studies related to the organizational sustainability have indicated a lot of special elements and dimensions for the organizational sustainability, where (AZua, 2012) indicated that the sustainability elements are identified in the following aspects (competence, effectiveness, knowledge development, positive ethical behavior, social responsibility, human capital development, organizational citizenship, creativity and innovation and organizational flexibility).

Whereas studies and researches have indicated the organizational sustainability dimensions according to the firm internal and external environment levels and both researchers have selected the following dimensions that serve the study objectives that were indicated by (Langenwalter, 2006) as the following:

A. Sustainability of Precise Assessment for the Clients' Needs: It means to gain and develop knowledge continuously concerning clients' needs, the changing extent in these needs, and new knowledge orientation toward products satisfying clients, contribute to good, positive relations construction and permanent with current clients also working on attraction of new customers (Al-Bakri, 2006)

B. Knowledge sustainability of current and future markets: It means enhancing, developing and preserving knowledge accumulation permanently linked to market variables, and work to transform this knowledge accumulation into intellectual rules that depend on a clear vision to understand and recognize markets orientations and its nature that allows the firm to exploit the available opportunities in the markets and to avoid risks existing therein. (AZua, 2012) 
C. Sustainability of organizational flexibility: It means the permanent firm ability to have flexibility to enter new markets according to the precisely calculated risk and to exploit the available and provided opportunities (Slaus \& Jacobs, 2011).

D. Firm competitiveness sustainability: It is the permanent and continuous firm ability to achieve competition superiority and create the excellence in the current markets with contribution to achieve a continuous and ongoing competitive advantage different from what the rivals possess (Whit, 2009).

\section{Mechanism Linking the Study Variables}

The study model included two major variables that are human resources management activities adopted in the value chain model and the organizational sustainability with its represented dimensions (Sustainability of Clients' Needs Assessment, Knowledge sustainability of current and future markets, Sustainability of organizational flexibility, Firm competitiveness sustainability). The human resources management activities adopted in the value chain model represent the independent variable of the study, whereas, the organizational sustainability with its four dimensions represents the dependent variable and the mechanism linking these both variables through explaining that the human resources activities is the tool adopted by the firm that contributes to the achievement of the organizational sustainability and may be explained through several aspects. The first aspect concerns the achievement way of human resources management activities for organizational sustainability through a set of activities as continuous development of the staff communication abilities, also communication development between clients and the firm in addition to the operation of enabling the staff. These aspects that adopt communication networks strategy that contribute to find easy and permanent communication channels between the firm and its clients (Barret et al, 2005). From another side, staff granting the powers to communicate and build interactive relations through which all opinions, notes and client needs are obtained and the extent of its change also to know the extent of their satisfaction, which helps to constitute a knowledge and build knowledge development about these needs and to study them in a manner achieving clients satisfaction and positively reflect on the relations between the firm and its customers that contribute to achieve their fidelity, preserve them and attract new customers (Flatt \& Standly, 2008). But the second aspect is concerning the way to achieve human resources management activities adopted in the value chain model to the knowledge sustainability of the current and future markets, where this is done through many activities (the activity of teamwork methods development, staff search skills development) (Lee, 2005). These activities contribute to the preparation of a set of collective workshops and a set of researches and studies leading to the collection of information that helps the firm to understand the current markets and their needs and features which result in the creation of a climate achieving confidence and stimulate the staff to cooperate and help the firm to respond positively to satisfy the requirements of these markets (Dobni, 2010). This is from one hand, and from the other, there is staff training and provide them with a set of new knowledge and skills enabling them to open new horizons, which help to rank, classify and develop serial construction that achieve quick response to these requirements (Bounchken \& Koch, 2007). From another angle, the human resources management activities adopted in the value chain model achieve organizational flexibility through a knowledge constitution about current and future markets, which contribute to the improvement of staff attitudes toward the change strategy that must be followed to conduct the required change that achieve preservation of the firm and its clients' interests positively and adopt new working means fit with the functions of the firm to serve its clients, increase their fidelity and obtain new customers (Najm, 2012).

But the aspect concerning the contribution method of the human resources management activities of the firm competitiveness sustainability, it is achieved through a group of operations (improvement staff attitudes toward the comprehensive quality philosophy, creativity psychological and social constitution, development of the staff creative abilities, encourage the staff initiatives) (Lovelock, 2009). These activities contribute to the obstacles removal facing creativity, initiatives, cancel negative feelings and encourage the positive aspects that pushes to creativity (Evans et al, 2007). This orientation helps the firm to adopt a set of new work strategies as (Critical thinking strategy, creative thinking strategy, mental models strategy, regular thinking strategy, Syncretic strategy and others) (Dohni, 2010). These strategies will push the firm and the staff to possess the ability to exit the familiar and present new concepts related to the work methods or products characterized by creativity through which it shall be superior to the competitors continuously and permanently (Al-Salem, 2012).

\section{Applied Study}

\subsection{Main Hypothesis Test}

(There is a statistically significant impact for the human resources management activities adopted in the value chain model on the realization of organizational sustainability in the Jordanian Pharmaceutical Industry Companies Sector). 
Table 6. Regression test results of the human resources management activities impact on organizational sustainability

\begin{tabular}{lllll}
\hline Correlation & Determination & Beta Coefficient & Value & Signification \\
Coefficient & Coefficient & B & F & Sig \\
\hline R & R2 & 0.47 & 96.07 & 0.00 \\
\hline 0.47 & 0.22 & 0.47 & Coffient
\end{tabular}

It is appeared through Table no. (6) that the Correlation Coefficient value for the impact of the human resources management activities adopted in the value chain model on the realization of organizational sustainability with its three dimensions amounted to (0.47) and the value of F amounted to (96.07), which is an indicator at the level of (0.05) and thus the hypothesis stipulating that the existence of the impact of the human resources management activities adopted in the value chain model on the realization of organizational sustainability with its dimensions is accepted. Also the above table shows that the beta value of (0.47), which reflects the positive impact also it is evident through value of R2 that competitive advantage explains the value of $(22 \%)$ of the variance, and $(78 \%)$ is due to other factors.

\subsection{First Sub-Hypothesis Test}

(There is a statistically significant impact for the human resources management activities adopted in the value chain model on the sustainability realization of customers' needs assessment in the Jordanian Pharmaceutical Industry Companies Sector).

Table 7. Regression test results of the human resources management activities impact on the sustainability of clients' needs assessment

\begin{tabular}{|c|c|c|c|c|}
\hline $\begin{array}{l}\text { Correlation } \\
\text { Coefficient } \\
\mathrm{R} \\
\end{array}$ & $\begin{array}{l}\text { Determination } \\
\text { Coefficient } \\
\text { R2 }\end{array}$ & $\begin{array}{l}\text { Beta Coefficient } \\
\text { B }\end{array}$ & $\begin{array}{l}\text { Value } \\
\mathrm{F}\end{array}$ & $\begin{array}{l}\text { Signification } \\
\text { Sig }\end{array}$ \\
\hline 0.56 & 0.31 & 0.56 & 43.31 & 0.00 \\
\hline
\end{tabular}

It is appeared through Figure no. (7) that the Correlation Coefficient value for the impact of the human resources management activities impact on the sustainability of clients' needs assessment in the firm amounted to (0.56) and the value of $\mathrm{F}$ amounted to (43.31), which is an indicator at the level of (0.05) and thus the hypothesis stipulating that (There is a statistically significant impact for human resources management activities impact on the sustainability of customers' needs assessment in the Jordanian Pharmaceutical Industry Companies Sector) is accepted. Also the above table shows that the beta value of (0.56), which reflects the positive impact also it is evident through value of R2 that competitive advantage explains the value of (31\%) of the variance, and (69\%) is due to other factors. This confirms the validity of the proposed model in the study.

\subsection{Second Sub-Hypothesis Test}

(There is a statistically significant impact for the human resources management activities adopted in the value chain model on the sustainability realization of the knowledge of current and future markets in the Jordanian Pharmaceutical Industry Companies Sector).

Table 8. Regression test results of the human resources management activities impact on the knowledge sustainability of the current and future markets

\begin{tabular}{|c|c|c|c|c|}
\hline $\begin{array}{l}\text { Correlation } \\
\text { Coefficient } \\
\mathrm{R} \\
\end{array}$ & $\begin{array}{l}\text { Determination } \\
\text { Coefficient } \\
\text { R2 }\end{array}$ & $\begin{array}{l}\text { Beta Coefficient } \\
\text { B }\end{array}$ & $\begin{array}{l}\text { Value } \\
\mathrm{F}\end{array}$ & $\begin{array}{l}\text { Signification } \\
\text { Sig }\end{array}$ \\
\hline 0.55 & 0.30 & 0.55 & 28.82 & 0.00 \\
\hline
\end{tabular}

It is appeared through Figure no. (8) that the Correlation Coefficient value for the impact of the human resources management activities impact on the knowledge sustainability of the current and future markets in the firm amounted to (0.55) and the value of F amounted to (28.82), which is an indicator at the level of (0.05) and thus the hypothesis stipulating that (There is a statistically significant impact for human resources management activities impact on the sustainability realization of the knowledge of current and future markets in the Jordanian Pharmaceutical Industry Companies Sector) is accepted. Also the above table shows that the beta value of (0.55), which reflects the positive impact also it is evident through value of R2 that competitive advantage explains the value of $(30 \%)$ of the variance, and $(70 \%)$ is due to other factors. This confirms the validity of the proposed model in the study.

\subsection{Third Sub-Hypothesis Test}

(There is a statistically significant impact for the human resources management activities adopted in the value chain model on the sustainability of organizational flexibility in the Jordanian Pharmaceutical Industry Companies Sector). 
Table 9. Regression test results of the human resources management activities impact on the sustainability of the organizational flexibility

\begin{tabular}{|c|c|c|c|c|}
\hline $\begin{array}{l}\text { Correlation } \\
\text { Coefficient } \\
\mathrm{R} \\
\end{array}$ & $\begin{array}{l}\text { Determination } \\
\text { Coefficient } \\
\text { R2 } \\
\end{array}$ & $\begin{array}{l}\text { Beta Coefficient } \\
\text { B }\end{array}$ & $\begin{array}{l}\text { Value } \\
\text { F }\end{array}$ & $\begin{array}{l}\text { Signification } \\
\text { Sig }\end{array}$ \\
\hline 0.50 & 0.25 & 0.50 & 44.92 & 0.00 \\
\hline
\end{tabular}

It is appeared through Figure no. (9) that the Correlation Coefficient value for the impact of the human resources management activities impact on the sustainability of the organizational flexibility in the firm amounted to (0.50) and the value of $\mathrm{F}$ amounted to (44.92), which is an indicator at the level of (0.05) and thus the hypothesis stipulating that (There is a statistically significant impact for human resources management activities impact on the sustainability of organizational flexibility in the Jordanian Pharmaceutical Industry Companies Sector) is accepted. Also the above table shows that the beta value of (0.50), which reflects the positive impact also it is evident through value of R2 that competitive advantage explains the value of $(25 \%)$ of the variance, and $(65 \%)$ is due to other factors. This confirms the validity of the proposed model in the study.

\subsection{Fourth Sub-Hypothesis Test}

(There is a statistically significant impact for the human resources management activities adopted in the value chain model on the sustainability of the competitiveness in the Jordanian Pharmaceutical Industry Companies Sector).

Table 10. Regression test results of the human resources management activities impact on the sustainability of the competitiveness

\begin{tabular}{lllll}
\hline Correlation & Determination & Beta Coefficient & Value & Signification \\
Coefficient & Coefficient & B & F & Sig \\
$\mathrm{R}$ & $\mathrm{R} 2$ & 0.63 & 64.45 & 0.00 \\
\hline 0.63 & 0.37 & Co3 &
\end{tabular}

It is appeared through Figure no. (10) that the Correlation Coefficient value for the impact of the human resources management activities impact on the sustainability of the competitiveness in the firm amounted to $(0.63)$ and the value of $\mathrm{F}$ amounted to (64.45), which is an indicator at the level of (0.05) and thus the hypothesis stipulating that (There is a statistically significant impact for human resources management activities impact on the sustainability of the competitiveness in the Jordanian Pharmaceutical Industry Companies Sector) is accepted. Also the above table shows that the beta value of (0.63), which reflects the positive impact also it is evident through value of R2 that competitive advantage explains the value of (37\%) of the variance, and (63\%) is due to other factors. This confirms the validity of the proposed model in the study.

\section{Conclusions and Recommendations}

\subsection{Conclusions of the Study}

Through the scientific methodical analysis of the study, the following conclusions may be determined:

1. The human resources management activities adopted in the value chain model indicate the organizational sustainability with its four dimensions (Sustainability of customers' Needs Assessment, Knowledge sustainability of current and future markets, Sustainability of organizational flexibility, competitiveness sustainability).

2. The organizational sustainability constitutes a modern reference for researchers, academics and administrative staff in the firms for its importance in the firms' continuity and success.

3. The human resources management activities contribute to generate new ideas which play a great role in supporting various major and supportive operations in the Value Chain Model.

4. Contributing in the creation of a new work environment characterized by the openness and share opinions, which contribute to the staff development and achieve competence and effectiveness.

5. Helping decision-makers in the different firms to take the correct procedures that contribute to the work development and success in the firm.

\subsection{Recommendations of the Study}

According to the results and conclusions of the study, it recommends the following:

1. The human resources management activities adopted in the value chain model in the Jordanian Pharmaceutical Industry Companies Sector shall be applied since they contribute to:

- Development of staff communication skills through their training on the art to deal with the clients. 
- Development of communication between the staff and customers through social networks strategy.

- Granting the staff wider powers in building interactive relations with the customers.

- Development of teamwork methods and notify each employee of his importance in the management and organization of these methods.

- Development of the staff research skills to perform a set of researches and studies related to the organizational sustainability and its different dimensions.

- Improvement of staff attitudes through adoption of a strategy for change.

- $\quad$ Enhancing positive aspects in the staff towards change and accept different ideas.

- Creation of quality culture in the staff of the firm.

- $\quad$ Providing a work power that believe in continuous change, improvement and development.

- $\quad$ Creating and enhancing motivation for creativity with the staff.

- Following different strategies to create new abilities in the staff and improving the abilities that they have.

- $\quad$ Encouraging the initiative and risk spirit in the staff.

\section{References}

Al-Bakre, T., \& Hamddan, K. (2013). The conceptual frame of sustainable and the Sustainable competitive advantage HP company simulating in the adoption for sustainability strategy. The academic for social and humanitarian studies, 9(1), 3-11.

Al-Mshhrawee, Z. (2015). The role of the rationalization accounting in supporting sustainability strategy, accounting point of view. Al-Azhar University Magazine, 17(1), 145-176.

Alnidawi (2015). Competitive advantage based on human capital and its impact on organizational sustainability, research presented to the Conference of Zitouna University of Jordan/ Faculty of Economics and Administrative Sciences.

Al-Nsoor, \& Abdel, H. (2009). the competitive performance of the Jordanian Pharmaceutical Industry Companies under economic openness, doctoral dissertation, Tishreen University, Latakia, Syria.

Al-Sakarneh, B. (2004). Pioneered strategies and its role in achieving competitive advantage and the development of performance in the Jordanian telecommunications companies sector, unpublished doctoral dissertation, Amman University, Jordan.

AZua, S. (2012). Sustainability strategies for the future: management, Innovation and Humanization, partner, International Journal of Contemporary hospitality management, 16(2), 117-130.

Barret, J., Grint, K., \& Nelson, D. (2005). Organizational leadership. United States: Library of congress Publishing.

Baum, T. (2006). Human recourse management for tourism, hospitality and leisure: an International perspective, London: Thomson.

Baumgartner, R. (2010). Sustainability strategies: Sustainability profiles and maturity corporate Responsibility Research conference, $4^{\text {th }}-5^{\text {th }}$ September, Dublin Published online 4 February in Wiley inter Science.

Bounchken, R., \& Koch, M. (2007). the role of Innovation orientations Strategies antecedent and innovation consequences of innovation orientation. International Journal of Technology intelligence and planning 3(3), 213-232. http://dx.doi.org/10.1504/IJTIP.2007.015770

Castro, J. J., \& Pedro, L (2006). Organizational Capital as Competitive advantage of the firm. Journal of intellectual capital, 7(3), 324-337. http://dx.doi.org/10.1108/14691930610681438

Charaghi, H., Khaligh, A., \& Naderi, A. (2012). Gaining competitive advantage marketing strategies in container terminal: A case study on shahid Raia.ee in Iran. International Business Research, 5(2), 179-191.

David, V. (2007). When Sustainability Become a chaUertge, opportunities for innovation Abound, January/2016 (www.enviormentalleader.com).

Dobni, C. (2011). The relationship between innovation orientation and organizational performance. International Journal of Innovation and learning, 140(3), 226-240. http://dx.doi.org/10.1504/IJIL.2011.042078

Evans, J. C., \& David, R. (2007). Operation management an integrated Services approach, Thomson, South western: USA. 
Flatt, S., \& Standley, J. (2008). Creating competitive advantage through Intangible assets: The Direct and indirect effects of corporate culture and Reputation. Advance in competitiveness Research, 16(12).

Hitchcock, D., \& Willard, M. (2009). The Business Guide to Sustalnabtrity.

Human, G., \& Naude, P. (2010). Innovation orientation in business and business context. South African Journal of business management, 41(4), 59-70.

Koch, N. (2009). Virtual Team leadership and collaborative Engineering advancement information Science Reference. Hershey. http://dx.doi.org/10.4018/978-1-60566-110-0

Kohher, P., \& Armstrong, G. (2007). Principle of marketing 11th Ed, Pearson prentice-Hall.

Landrum, N., \& Edwards, S. (2009). Sustainable Business: An Executive's Primer, New York: Business Expert press. http://dx.doi.org/10.4128/9781606490495

Langenwalter, G. (2006). Life is our Ultimate Customer: From lean to Sustainabillty. Target Magazine, 22(1), 5-15.

Lee, C., \& Jung, C. (2005). the effects Internal Marketing and organizational Cultural on Knowledge Management in the information Technology Industry. International of management, 22(4), 661-672.

Lovelock, C. (2009). Essential of Marketing, Singapore: Prentice Hall.

Mow, F. M., \& Munt, I. (2009). Sustainability Third: New Tourism in the Third world, $3^{\text {rd }}$ edition London: Row ledge.

Najm, N. (2011). Administrative leadership in the twenty-first century Dar Al Safa for Publishing and Distribution: Jordan.

Porter, M. (1985). Competitive advantage, Free press, New York: USA.

Slause, I., \& Jacobs, G. (2011). Human capital and Sustainability. Journal Sustainability, 3(7), 100-120.

Steven, S. W. (2007). Production/ Operation management, Von Hoffmann press, Saint Louis: USA.

White, P. (2009). Building a Sustainability strategy into the business corporate government 9(4), 386-394

Zemilthaml, V. (2008). Service marketing integration customer focus Accrue the Firm, New York: Mc Grew- Hill Erwin

\section{Copyrights}

Copyright for this article is retained by the author(s), with first publication rights granted to the journal.

This is an open-access article distributed under the terms and conditions of the Creative Commons Attribution license (http://creativecommons.org/licenses/by/3.0/). 